\title{
Opieka nad kobietą i dzieckiem z zespołem FAS
}

\section{Care of woman and child of FAS syndrome}

\author{
AGNIESZKA KOMOROWSKA ${ }^{1,2}$ \\ ${ }^{1}$ Instytut Nauk o Zdrowiu, Państwowa Wyższa Szkoła Zawodowa we Włocławku \\ ${ }^{2}$ Wydział Nauk o Zdrowiu, Wyższa Szkoła Gospodarki Krajowej w Kutnie
}

DOI: http://dx.doi.org/10.21784/IwP.2018.012

ISSN: 2451-1846

\section{Streszczenie:}

FAS czyli Płodowy Zespół Poalkoholowy to jednostka chorobowa obejmująca nieprawidłowości neurobehawioralne oraz zmiany w organach wewnętrznych. Nieprawidłowości te występują u dzieci, których matki spożywały alkohol w okresie ciąży.

Dzieci z FAS oprócz licznych zmian w budowie ciała mają problemy z koncentracją uwagi, komunikowaniem się, nieumiejętnością rozwiązywania problemów oraz ze słabą kontrolą impulsów. Trudności rozwojowe, jakie występują u tych dzieci wynikają z powodu uszkodzenia Ośrodkowego Układu Nerwowego.

Bardzo ważnym elementem jest wdrażanie profilaktyki wśród kobiet, która ma na celu ograniczenie spożywania alkoholu przez kobiety ciężarne. Opieka perinatalna nad kobietą ciężarną powinna być już prowadzona przed ciążą oraz podczas porodu. Natomiast opieka poporodowa nad kobietą i jej dzieckiem powinna mieć na celu zapewnienie kontaktów z ośrodkiem specjalistycznym i poradnictwem antyalkoholowym.

Celem pracy było przedstawienie i omówienie problemów związanych ze spożywaniem alkoholu przez kobiety ciężarne oraz omówienie wad, jakie występują u dzieci, których matki spożywały alkohol w okresie ciąży. Kolejnym ważnym aspektem było przedstawienie metod profilaktyki wśród kobiet spożywających alkohol oraz omówienie opieki okołoporodowej nad matką i jej dzieckiem. 
Słowa kluczowe: płodowy zespół poalkoholowy, opieka, dziecko, matka

\begin{abstract}
:
FAS- Fetal Alcohol Syndrome - is a disease consisting in neurobehavioral incorrectness as well as some changes in internal organs. This incorrectness occur at these children whose mothers drank alcohol during pregnancy.

The FAS-children, apart from numerous changes in a body build, have problems with notice concentration, communication, incompetence of solving problems as well as with a weak impulse control. Their growing difficulties result from injury to Central Nerve system.

Implementation of prophylaxis for the women is very important. It has in view to limit drinking alcohol by the pregnant women. The prenatal care of the pregnant women and her child is carried on by specialist health service centre and anti-alcoholic clinics.

My work aimed at representing and trating defects that occur at these children whose mothers drank alcohol during pregnancy. The representing of methods of prophylaxis for the alcohol drinking women and trating a post - natal care of the mother and her child was a very important element of the paper.
\end{abstract}

Keywords: Fetal Alcohol Syndrome, care, child, mother

\title{
Wstęp
}

Picie alkoholu prze kobiety ciężarne wpływa na wewnątrzmaciczny rozwój płodu zaburzając rozwój somatyczny i funkcjonalny Ośrodkowego Układu Nerwowego. Skutki tych zaburzeń są długotrwale, powodują upośledzenie funkcjonowania układu nerwowego nierzadko do końca życia.

Dzieci po prenatalnej ekspozycji na alkohol często są diagnozowane jako nadpobudliwe, autystyczne, rozwijające się nieharmonijnie, tymczasem ich problemami są różnego rodzaju uszkodzenia organów, w tym mózgu, zwiane ze spożywaniem alkoholu przez ich matki podczas ciąży [3,4]. 
Współcześnie niezwykle ważna jest identyfikacja kobiet z grup wysokiego ryzyka picia alkoholu w ciąży. Wczesna identyfikacja problemu i odpowiednie wczesna skuteczna interwencja może w dużym stopniu ograniczyć częstość negatywnych skutków wewnątrzmacicznej ekspozycji płodu na działalnie alkoholu etylowego.

FAS, czyli Płodowy Zespół Alkoholowy, to jednostka chorobowa obejmująca nieprawidłowości neurobehawioralne oraz zmiany w budowie ciała, organach wewnętrznych. Nieprawidłowości te występują u dzieci matek, które spożywały alkohol w czasie ciąży. Jedyną przyczyną występowanie FAS jest spożywanie prze kobietę ciężarną. Kobieta spożywająca alkohol w czasie trwania ciąży dostarcza go także swojemu dziecku. Alkohol przenika przez łożysko. Alkohol krążący w organizmie dziecka może nieodwracalnie uszkodzić mózg oraz powodować powstawanie innych defektów i zaburzeń. W każdym trymestrze mogą wystąpić specyficzne skutki spożywania alkoholu. W pierwszym trymestrze mogą pojawić się zaburzenia w migracji komórek, których wynikiem mogą być poronienia lub wady rozwojowe płodu. $\mathrm{W}$ drugim trymestrze powstaje najwięcej zmian dymorficznych i uszkodzeń w OUN (Ośrodkowy Układ Nerwowy). W trzecim trymestrze dochodzi do pogłębienia się uszkodzeń w OUN powstałych we wcześniejszym okresie ciąży[2,6,7].

Każda ilość wypitego alkoholu prze kobietę ciężarną może spowodować ryzyko wystąpienia zaburzeń w rozwoju dziecka. Jeśli dziecko nie będzie miało FAS, to i tak istnieje prawdopodobieństwo pojawienie się nieco lżejszych zaburzeń i uszkodzeń, jak:

- Alkoholowy Efekt Płodowy (FAE) - mniejsza ilość powstałych defektów u dziecka,

- uszkodzenia płodu spowodowane alkoholem, np. wady serca, wzroku, słuchu, anomalie stawów,

- poalkoholowe zaburzenia układu nerwowego, np. zaburzenia uwagi $[1,8,9,10]$.

Nigdy nie można postawić diagnozy opartej na wyglądzie zewnętrznym czy dane dziecko posiada FAS, jednak istniejąc cechy 
dysmorficzne, które mogą wskazywać na podejrzenie FAS, a należą do nich:

- skrócenie szpar powiekowych (mniejsza niż u przeciętnego dziecka odległość miedzy wewnętrznymi i zewnętrznymi kącikami oczu),

- opadające powieki (jedna lub obydwie),

- szeroko rozstawione oczodoły,

- szeroka nasada nosa,

- spłaszczona środkowa część twarzy,

- brak rynienki podnosowej,

- słabo rozwinięta żuchwa (małożuchwie),

- nisko osadzone, zniekształcone małżowiny uszne,

- deformacje małych stawów rąk i inne.

\section{Przegląd literatury}

\section{Charakterystyka uszkodzeń OUN związanych z prenatalną ekspozycją na alkohol}

Dzieci z FAS oprócz licznych zmian w budowie ciała mają przede wszystkim uszkodzony mózg. Uszkodzenie mózgu prowadzi do trudności w uczeniu się, zaburzeń zachowania, deficytów pamięci, zespołu ADHD lub opóźnień rozwojowych. Problemami obserwowanymi przy uszkodzeniu pnia mózgu są:

- zaburzenia snu,

- trudności z połykaniem pokarmu i wody (dysfagia),

- trudności z oddychaniem (również ważne dla rozwoju mowy),

- trudności z organizacja otoczenia i z odbieraniem bodźców,

- zawroty głowy i mdłości,

- problemy z równowagą i ruchem.

Czasami zdarza się, że dzieci mające niewielkie wady fizyczne nie radzą sobie $\mathrm{z}$ prostymi zadaniami poznawczymi, ponieważ związane jest to $\mathrm{z}$ teratogennym działaniem alkoholu na Ośrodkowy 
Układ Nerwowy. Większość niemowląt z FAS jest obudzonych. Ma trudności z jedzeniem, jest nadwrażliwa na bodźce. Może mieć hipertonię (zbyt duże napięcie mięśniowe) lub hipotonię (zbyt małe napięcie mięśniowe). Najbardziej groźne cechy charakterystyczne FAS to subtelne objawy uszkodzenia układu nerwowego będące rezultatem narażenia na działalnie alkoholu w życiu płodowym. Dzieci $\mathrm{z}$ FAS/FAE nawet $\mathrm{w}$ wieku kilkunastu lat nie potrafią zapanować nad swoimi reakcjami i emocjami. Słabe zdolności adaptacyjne są jednym $\mathrm{z}$ najwcześniej występujących sygnałów dysfunkcji Ośrodkowego Układu Nerwowego. Poalkoholowe niemowlęta miewają wydłużonym czas reagowania na bodźce. U niemowląt widoczne są także zaburzenia $\mathrm{w}$ funkcjonowaniu intelektualnym i motorycznym. Prenatalny wpływ alkoholu na rozwój umysłowy i motoryczny dzieci może być niezauważalny, aż do wieku 18-24 miesięcy. Zależne od alkoholu zmiany mają głównie charakter komórkowy. Alkohol zaburza rozwój niektórych obszarów mózgu (zwoje podstawy-zwłaszcza jadro ogoniaste, ciało modzelowate) poprzez zaburzenie normalnego wzorca migracji komórek mózgowych do miejsca przeznaczenia, co zachodzi podczas embriogenezy i histogenezy OUN. Charakterystyczna cecha ekspozycji na alkohol w okresie życia płodowego są zmiany w móżdżku, szczególnie jego zmniejszenie. Zjawisko to tłumaczone jest przedwczesnym obumieraniem niektórych typów komórek nerwowych. Prenatalna ekspozycja na działanie alkoholu etylowego w całym okresie trwania ciąży, a w szczególności w I trymestrze ma wpływ na rozwój różnych obszarów mózgu. Powstające na skutek takiej ekspozycji ubytki neuropsychologiczne mogą dawać trudny do diagnostyki obraz o różnym nasileniu zmian. Można przypuszczać, ze zmiany, do jakich dochodzi w czasie rozwoju mózgu mogą utrzymywać się również w życiu dorosłym $[4,8,11,12]$.

\section{Neuropsychologiczny profil dziecka z FAS}


Trudności rozwojowe dziecka z FAS wynikają z uszkodzenia OUN. Dzieci z FAS posiadają różnorodne uszkodzenia mózgu, zależą one miedzy innymi od tego, w którym okresie ciąży matka wypiła alkohol. W funkcjonowaniu dzieci z FAS obserwujemy następujące zaburzenia w rozwoju: motoryki małej i dużej, zaburzenia sensoryczne, zaburzenia związane $\mathrm{z}$ uczeniem się, trudności językowe, społeczne, w samodzielnym funkcjonowaniu czy zaburzenia psychiczne. Powyższe zaburzenia mogą mieć podłoże organiczne $\mathrm{w}$ postaci uszkodzeń ośrodkowego układu nerwowego $[4,12,13]$.

W zaburzeniach motoryki dużej obserwujemy problemy $\mathrm{z}$ równowaga oraz brak koordynacji ruchowej. U dzieci, u których podejrzewa się uszkodzenia móżdżku bądź rdzenia kręgowego wykonuję się próbę Romberga, która polega na zbadaniu zborności ruchów. U dzieci z problemami w zakresie motoryki malej występuje apraksja konstrukcyjna, apraksja drenowo-ruchowa, słaba koordynacja pracy rąk i oczu. Apraksja konstrukcyjna spowodowana jest uszkodzeniem Plata ciemieniowego mózgu. Dziecko z tym zaburzeniem ma kłopoty z napisaniem całego słowa i odpowiednim przestrzennym rozmieszeniem liter i wyrazów. U niektórych dzieci występują również drżenia zacierowe, które utrudniają precyzyjne wykonywanie ruchów. U młodszych dzieci obserwuje się także zaburzenia rozwojowe $\mathrm{w}$ postaci braku organizacji motorycznej. Sygnałem ostrzegawczym u dzieci w dziewiątym miesiącu życia, które może świadczyć o zaburzeniach w motoryce jest moment, w którym dziecko nie siada samo, nie stoi $\mathrm{z}$ podparciem, nie chwyta przedmiotów w palce. Natomiast w dwunastym miesiącu życia może być to, iż dziecko nie stoi samo nawet przez moment, nie wykonuje paru kroków z podtrzymywaniem prze rodziców, nie chwyta drobnych przedmiotów z udziałem kciuka [7,11,13].

Dzieci posiadające zaburzenia sensoryczne maja trudności z odczuwaniem bodźców takich jak: ból, pragnienie, głód. Mogą także mieć nieprawidłowe odczucia wzrokowe, słuchowe, smakowe, 
węchowe, dotykowe, ale również mogą występować halucynacje. Występują także zaburzenia regulacji zwiane $\mathrm{z}$ przetwarzaniem bodźców sensorycznych. Oprócz zaburzeń uwagi, występują również zaburzenia $\mathrm{w}$ uczeniu się $\mathrm{i}$ inteligencji, zaburzenia funkcji poznawczych, w rozwoju mowy i komunikacji, czy psychiatryczne jako konsekwencja uszkodzenia OUN. Badacze w USA zaproponowali aby problemy psychiatryczne, które mogą pojawić się u dziecka z FAS, opisywać w kategorii Zaburzenia Umysłowe Spowodowane Stanem Zdrowia. W USA oprócz skali DSM-IV używa się w praktyce również opisu klinicznego według klasyfikacji diagnostycznej, tzw. „Zero do Trzy" (Zero to three, 1994 za: O'Malley, 2007). Klasyfikacja ta została opisana do potrzeb diagnostycznych dzieci z zaburzeniami w zakresie zdrowia psychicznego poniżej trzeciego roku życia. Skala ta uwzględnia zaburzenia psychiczne, sensoryczne, zaburzenia relacji $\mathrm{z}$ matką związane $\mathrm{z}$ przywiązaniem. U dzieci $\mathrm{z}$ FAS można zaobserwować także zaburzenia afektywne związane $\mathrm{z}$ labilnością emocjonalną, płaczliwością oraz ataki paniki $\mathrm{z}$ hiperwentylacją $[11,12,15]$.

\section{Pomoc psychologiczno-pedagogiczna dzieciom z zespołem FAS}

Proces uczenia się i nabywania nowych umiejętności dla dzieci z FAS, jest bardzo skomplikowany i trudny ze względu na alkoholowe uszkodzenie mózgu. Podstawą ich rozwoju jest usprawnianie systemów sensorycznych oraz procesów układu nerwowego. Ważny jest stały dopływ do mózgu. Dzięki stymulacji wielozmysłowej mózg otrzymuje informacje ze wszystkich zmysłów i integruje je $\mathrm{z}$ wcześniejszymi doświadczeniami. To zmysły dostarczają informacji z otoczenia do mózgu. Barak lub niski poziom stymulacji powoduje hamowanie uczenia się. Dlatego tez dziecku należy dostarczać bodźców zmysłowych różnego rodzaju: wzrokowych, słuchowych, węchowych, czuciowych. Dzieci z FAS wymagają nauczania polisensorycznego. Nie można u tych dzieci wykorzystywać jedynie tylko zmysłu słuchu lub wzroku $[3,6,9]$. Dzieci 
muszą dotykać, manipulować, zmieniać pozycje ciała, ponieważ tylko w ten sposób zwiększymy ich szanse i potencjalne możliwości.

Bardzo ważną rolę $\mathrm{u}$ dzieci spełnia diagnostyka przeprowadzona za pomocą testów i profili rozwojowych po to, aby określić i zaproponować odpowiedni sposób postępowania i terapii. Oto przykładowe badania, jakie może zlecić lekarz:

- badanie audiologiczne- pozwalają określić objawy świadczące o nadwrażliwościach lub niedowrażliwościach słuchowych,

- badanie rentgenowskie czaszki- można wziąć je pod uwagę, gdy podejrzewa się wadliwy rozwój czaszki albo zwapnienie wewnątrzczaszkowe,

- tomografia komputerowa (CT) mózgu - jest to pierwsza technika, która umożliwia bezpośrednie obrazowanie mózgu. Badanie tomograficzne mózgu jest skuteczne w wykrywaniu guzów, wodogłowia, torbieli, wrodzonych anomalii.

- rezonans magnetyczny (MRI)- technika ta pozwala uzyskać przekrojowe obrazy mózgu. Badania MRI mózgu charakteryzują się większa skutecznością, jeśli chodzi o wykrywanie nieprawidłowej mielinizacji oraz defektów pnia mózgu i móżdżka,

- elektroencefalografia (EEG) - ta technika mierzy zmiany aktywności elektrycznej na powierzchni mózgu. Badanie to jest pomocne, gdy podejrzewa się zaburzenia napadowe u dzieci z FAS $[6,11,15]$.

Techniki behawioralne koncentrowane są na konkretnych zachowaniach i umiejętnościach. Ich efekt uzależniony jest przede wszystkim od systematyczności, konsekwencji właściwego stosowania, wzmacniania i niwelowania zachowań właściwych i pozytywnych. Takie techniki są bardzo przydatne u dzieci z FAS, które mają zapotrzebowanie na jasność, konkretność, powtarzalność. Przy stosowaniu technik behawioralnych należy wykorzystywać zasadę stopniowania, to znaczy poszczególne techniki behawioralne należy wprowadzać stopniowo, natomiast nie należy wprowadzać 
wszystkich form technik w tym samym czasie. Dzięki technikom behawioralnym polepsza się sytuacja społeczna dziecka, między innymi ono samo wie jak ma się zachować i co robić. $W$ opiece nad dzieckiem z zespołem FAS można wykorzystywać również inne formy pomocy takie jak muzykoterapię, socjoterapię czy stałość otoczenia $[7,9,12]$.

\section{Profilaktyka i opieka perinatalna wśród kobiet}

Działania zapobiegawcze prowadzone w czasie ciąży można usystematyzować dzieląc je na trzy stopnie. Podział taki wówczas jest uwarunkowany możliwościami diagnostycznymi i ograniczeniami czasowymi. Działania zapobiegawcze pierwszego stopnia zwane inaczej uniwersalnymi, polegają na informowaniu wszystkich zgłaszających się pacjentek o negatywnych skutkach wewnątrzmacicznej ekspozycji płodu na działanie alkoholu etylowego. Kobiety ciężarne powinny być zawsze pytane o spożywanie alkoholu, a w przypadku kobiet pijących należy przeprowadzić indywidualne działania zapobiegawcze mające na celu zaniechanie lub zmniejszenie ilości spożywanego alkoholu. Osoba, która przeprowadza rozmowę z pacjentką powinna podkreślić, że nie została określona bezpieczna dawka spożywania alkoholu w okresie ciąży. W miejscu gdzie przyjmowane są kobiety ciężarne powinny znajdować się informacje dotyczące Płodowego Zespołu Alkoholowego i negatywnych skutków spożywania alkoholu w czasie ciąży $[2,7,8]$. Działania profilaktyczne pierwszego stopnia (uniwersalne) polegają na powstrzymaniu przyszłej matki od picia alkoholu oraz konieczności zaprzestania picia alkoholu w czasie ciąży, a także stosowanie skutecznej antykoncepcji w przypadku naużywania alkoholu. Pacjentka powinna wiedzieć, że zaprzestanie picia alkoholu w każdym okresie ciąży zwiększa szanse na urodzenie zdrowego dziecka. Działania zapobiegawcze drugiego stopnia zwane inaczej wybiórczymi, mają charakter interwencyjny i są skierowane do grupy kobiet o wysokim stopniu ryzyka wystąpienia problemu 
spożywania i nadużywania alkoholu etylowego. Obejmują one określenie ilości spożywanego alkoholu w ciąży oraz oceny poziomu ryzyka, przeprowadzenie interwencji, a w przypadku braku efektu interwencji- skierowanie kobiet do ośrodka specjalistycznego $[4,6,9]$.

Celem działań drugiego stopnia jest interwencja przed ciążą lub we wczesnym jej okresie, która ma na celu zaprzestanie lub wyraźne ograniczenie spożywania alkoholu etylowego przez kobietę ciężarną. Identyfikacja problemu i wczesna skuteczna interwencja może w dużym stopniu ograniczyć częstość negatywnych skutków wewnątrzmacicznej ekspozycji płodu na działanie alkoholu. Działania zapobiegawcze trzeciego stopnia skierowane są do pacjentek z rozpoznanym w czasie ciąży problemem używania lub nadużywania alkoholu etylowego. U pacjentek występuje duże ryzyko urodzenia dziecka z Płodowym Zespołem Alkoholowym (w tym głównie z uszkodzeniami OUN) spowodowane spożywaniem alkoholu w czasie ciąży. Opieka prowadzona nad kobietą wymaga bardzo dużego zaangażowania zespołu specjalistycznego oraz interdyscyplinarnego. Opieka prowadzona nad kobietą ciężarną powinna być podjęta już przed ciąża i sprawowana także w okresie ciąży, porodu oraz bezpośrednio po nim. Opieka nie powinna tylko i wyłącznie obejmować matkę dziecka, ale również samo niemowlę[3,9,15].

\section{Wnioski}

1. Każda ilość alkoholu wypitego przez kobietę ciężarną może spowodować ryzyko wystąpienia zaburzeń w rozwoju dziecka lub nieco lżejszych zaburzeń i uszkodzeń jak: FAE lub Poalkoholowe Zaburzenia Układu Nerwowego.

2. Bardzo ważną rolę u dzieci $\mathrm{z}$ FAS spełnia diagnostyka przeprowadzona za pomocą testów i profilów rozwojowych, która pozwala określić i zaproponować odpowiedni sposób terapii. 
3. Opieka prowadzona nad kobietą wymaga zaangażowania specjalistycznego zespołu interdyscyplinarnego.

\section{Bibliografia/Bibliography:}

1. Bartel H., Embriologia. Wyd. Lek. PZWL, Warszawa 2004, 220-223.

2. Kazdepska-Zimińska A. Jagielska I. Kaźmierczak J. Noworodek prenatalna ekspozycja na alkohol. Perinatologia, Neonatologia, Ginekologia 2013; 6: 40-43.

3. Hryniewicz D. Specyfika pomocy psychologiczno-pedagogicznej dzieciom z FAS. Wydawnictwo Edukacyjne Parpamedia; Warszawa 2007.

4. Laskowska B. Alkoholizm matki a jego destrukcyjny wpływ na dziecko. Studia nad Rodziną 1998; 2: 177-185.

5. Klecka M. Objawy i wczesne rozpoznanie FAS. http://www.niebieskalinia.pl/pismo/wydania/dostepneartykuly/4500-objawy-i-wczesnerozpoznanie-fas

6. Szczupał B. Dziecko z FASD - problemy diagnostyczne oraz wybrane strategie i metody pracy. Rozprawy Społeczne 2013; 1: 79-87.

7. Liszcz K. Dziecko z FAS w domu i w szkole. Wydawnictwo Rubikon, Kraków 2011.

8. Klecka M. Fetal Alcohol Syndrome - Alkoholowy Zespół Płodowy. Poalkoholowe dzieci ze złożoną niepełnosprawnością. Dziecko Krzywdzone 2004; 8: 46-55. 158

9. Lewicka M. Płodowy zespół alkoholowy jako czynnik wykolejenia społecznego. W: M. Boczkowska, E. Tymoszuk, P. Zielińska (Red.) Wychowanie, profilaktyka, terapia. Szanse i zagrożenia. Oficyna Wydawnicza Impuls, Kraków 2012: 215-225. 
10. Liszcz K. Nadzieja $\mathrm{w}$ nas. Dzieci $\mathrm{z}$ alkoholowym zespołem płodowym. Niebieska Linia.2006; 3

http://www.niebieskalinia.pl/pismo/rocznik-2006/153-

czasopismo/artykuly-nl/4586-nadzieja-w-nas-dzieci-z-

alkoholowym-zespolem-plodowym

11. Klimczak J. Fetal Alcohol Syndrom - czyli skutki oddziaływania alkoholu na płód. W: Banach M. (Red.) Alkoholowy zespół płodu. Teoria. Diagnoza. Praktyka. Wyższa Szkoła FilozoficznoPedagogiczna Ignatianum, Wydawnictwo WAM; Kraków 2011: 147155.

12. Klecka M. Janas Kozik M. Dziecko z FASD. Rozpoznania różnicowe i podstawy terapii. Warszawa: Państwowa Agencja Rozwiązywania Problemów Alkoholowych, Warszawa 2009.

13. Klecka M. FAScynujące dzieci. Wydawnictwo Św. Stanisława BM Archidiecezji Krakowskiej, Kraków 2007.

14. Mrozowska M. Problemy diagnostyczne dzieci z FASD. W: Banach M. (Red.) Alkoholowy zespół płodu. Teoria. Diagnoza. Praktyka. Wyższa Szkoła Filozoficzno-Pedagogiczna Ignatianum, Wydawnictwo WAM, Kraków 2011: 235-253.

15. Sarnacka B. Dzieci z FAS. W: Jarkiewicz K. (Red.) Oblicza pedagogii. Wyższa Szkoła Filozoficzno-Pedagogiczna Ignatianum, Wydawnictwo WAM, Kraków 2005: 173-185. 